\section{OF ABDOMINAL INJURY}

\section{FREDERICK G. DYAS, M.D.} CIIICASio Mistory-Mr. F. A., aged 30, was shot from below, by a
person standing on the sidewalk, the bullet going through a
window and strik patient was striking lim in the right lumbar region. The anee of considerable the hospital, and presented the appear. rigidity. The slibec, with marked abdominal pain and injury with ablominal findings were those of peritoneal was 100, tentard distention, tenderness and pain. 'The pulse operation aud tatere of $\mathrm{F}$. The patient was prepared for tion at that tiaken to the operating-room, but refused operalowing molninge, it leing 2 o'clock in the morning. The folthe patient wing at 9 o'clock, the symptoms not having abated, tion, to which he con consulted and urged to submit to operaoperation we consented.

above the above the umbilieus, and the liver, gall-bladder, stomach, spleen evidence of injury were carefully gone over without finding any in the peritonewy to them or any fluid or intestinal contents the umbilicuseal eavity. A second incision was made below this incision, and the abdominal contents examined through having been, without finding any lesion. Examination of urine felt that made withont finding any blood or albumin, it was was elosed the kidneys had escaped injury, and the abdomen subsed lip, with drainage.

Subsequent Course.-The following day the patient developed tinued to ination of temperature and the temperature contemperaturerease on succeding days, until he had a daily Ply ture of $101 \mathrm{~F}$.

fludidysical examination of the cluest revealed the pressure of The patient pleural cavity on the same side as the injury. wounds. weoks and the findings in the chest cleared up after. three The patient was discharged as cured.

the explanation of the clinical findings of injury to the peritoneal contents, I believe, lies in the fact that infected and portion of the pleura was injured and as is so and the pain was transferred to the abdomen, is so frequently observed in lower lobe pnenmonia.

no surgeo that with the symptoms above enumernted, aldomen would have been justified in leaving the commen unopened, and that we have no means at our a wound at the present time of discriminating between toms, and the pleura which produces abdominal sympsound of the ablomen itself.

Sanitary Control of Public Milk-Supply.- "The importance Prof. controlling the quality of the public milk-supply." says quently. O. Jordan (Science, Jume 2, 1911), "although frethe present urged by sanitarians, is not always appreciated. At safe to time, in a great majority of Amerien cities, it is drink to say that for every case of infectious disense due to difficult to of the to secure adequate funds for the sanitary control not the milk-supply. By sanitary control of milk is meant, total solidsholding of a rigorous standard of butter-fat and liness and but the maintenance of proper standards of cleaning the and health for dairy cows and especially the safeguardtation. milk free from infection during collection and transporagainst Under some conditions the protection of the consumer compulsory-borne infection may be best brought about by which pory pasteurization of that portion of the milk-supply ever method otherwise be raised to proper standard. Whatgenuinethod of control may be adopted, it is certain tlat any followed in rovement in the character of a milk-supply will be typhoid in the long run by a lessening in the amount of detection fever and to some extent tuberculosis. The early dairy farm a single case of typhoid fever or scarlet fever on a sive farm may be the means, not only of preventing an extenfoci epidemic, but of avoiding the formation of scores of new soci which can ... light up subsequent cases for many years."

\section{Therapeutics}

\section{CHOLIERA INFANTUM; SUMMER DIARRHEA OF} INFANTS

Probably both of the designations at the hend of this article will soon be entirely banished from scientific nomenclature. At the present time, however, it is convenient to use them, even if they are not scientifically accurate, to indicate a class of diseases which are seen during the hot weeks of summer. It was formerly the custom to limit the use of the term "cholera infantum" to attacks of diar'rhea with watery movements, accompanied by vomiting and great prostration, which cmme on suddenly, and often resulted in death. At the same time it was the custom with many physicians to ajply the name to all cases of diarrhea with vomiting seen in young children, so that the accounts given by medical men of this trouble have been more or less inexact. Not properly included within this class are the very large number of cases of diarrhen in children which come on more or less gradually and which often are not so severe as the cases previously spoken of. In some of these cases, besides the diarrhea, vomiting is a prominent symptom. In other cases, vomiting is nearly or completely absent. The movements frequently contain blood, mucus, or pus, and are accompanied by pain and tenesmus. 'The former class of cases are commonly designated as acute gastro-enteritis, the latter. as enterocolitis.

\section{IETIOLOGY}

Several factors are obviously concerned in the production of these diarrhenl disorders. Formerly, the high temperature prevalent during the greater part of July and August was supposed to have an important influence in causing the disense. More recently, with the increasing attention paid to the study of bac. teriology, and especially to the study of the so-called intestinal flora, a fermentation of the food, producerl by the growth and development of the bacteria, is believed to be the most important element in the production of these diseases. Now, it is assumed by many thint the deleterious influence of the high temperature of the summer is chiefly productive of disease by encouraging the fermentation and putrefaction of the different articles presented to the child as food, and particularly causing the growth and development of bacteria in milk, with the consequent fermentation and putrefuction and production of various sorts of toxins. The etiologic factor of disease, "cold or chilling," to which so much was formerly attributed in causing disease, has been almost forgotten. Few now stop to consider that possibly the chilling of the surface of the body, during cool nights, or by exposure to drafts, may so interfere with the normal processes of digestion as to produce a gastroenteritis.

\section{PROPIIYLAXIS}

It is impossible to overestimate the importance of properly instructing parents and care-takers how to feed infants and young clildren so that they may avoid attacks of these disastrous diseases. It is not necessary to stop here to discuss the desirability of feeding infants at the mother's breast until they are at least 6 months old, and perhaps a year old. The occurrence of diarrheal diseases in breast-fed infants is infrequent, and the mortality is very slight. A common grave mistake in the feeding of children under 2 years old is to give them everything which the adults of the family eat, 